\title{
Pragmatism and Emergentism
}

In Chauncey Wright's Evolutionary Philosophy

\section{Andrea Parravicini}

\section{(2) OpenEdition Journals}

Electronic version

URL: http://journals.openedition.org/ejpap/1623

DOI: 10.4000/ejpap.1623

ISSN: 2036-4091

Publisher

Associazione Pragma

Electronic reference

Andrea Parravicini, «Pragmatism and Emergentism », European Journal of Pragmatism and American Philosophy [Online], XI-2 | 2019, Online since 24 December 2019, connection on 15 June 2020. URL http://journals.openedition.org/ejpap/1623 ; DOI : https://doi.org/10.4000/ejpap.1623

This text was automatically generated on 15 June 2020 .

\section{(c) $($ () $\ominus$}

Author retains copyright and grants the European Journal of Pragmatism and American Philosophy right of first publication with the work simultaneously licensed under a Creative Commons AttributionNonCommercial-NoDerivatives 4.0 International License. 


\title{
Pragmatism and Emergentism
}

\author{
In Chauncey Wright's Evolutionary Philosophy
}

\author{
Andrea Parravicini
}

\section{AUTHOR'S NOTE}

The author thanks the anonymous reviewers for valuable comments.

\section{Introduction}

\subsection{Current Debates on the Notion of "Emergence"}

During the last twenty-five years, the notion of "emergence" has gained renewed attention in different fields, from evolutionary biology to cognitive sciences, from social sciences to philosophy of mind. ${ }^{1}$ This interest is connected to the possible application of the notion of emergence in the study of complex systems and to the possibility of developing a "non-reductive physicalism" (Crane 2001: 207). Emergence generally describes a new property or entity appearing when a system reaches a certain threshold of complexity. Although the emergent element must be connected to the system from which it emerges, it must also be novel (Bennett-Hunter 2015). Furthermore, "emergence" is related to a middle road between radical dualism and reductionism, i.e. to a theoretical position according to which the emergent phenomenon (e.g., biological life or consciousness) is "grounded in and yet emergent from the underlying material structure with which it is associated" (O'Connor 1994: 91).

In the contemporary debate, there is neither consensus about a shared definition of the term "emergence," nor a homogeneous use of the notion across the research fields where it applies. Current theories of emergence thus disagree as to how "emergent" phenomena ought to be interpreted (see Brioschi 2013, part I). An ontological view argues for the real status of the emergent novelties, considered to be real components of the world and irreducible to the lower level from which they originated (Bunge 
2003). An epistemological view claims that "emergence" is "in the eyes of the beholder," i.e. that it is an object of our patterns of knowledge (Hempel \& Oppenheim 1948; Baas \& Emmeche 1997). Further important problems lie in the way we are to understand emergence, whether in a weak or strong sense. According to Chalmers (2006), we refer to a weak emergent phenomenon when "truths concerning that phenomenon are unexpected given the principles governing the low-level domain," but deducible from them, while we interpret the emergence in a strong sense when "truths concerning that phenomenon are not deducible even in principle from truths in the low-level domain" (ibid.: 244).

Jaegwon Kim (1999: 20-4) has singled out some core topics in the current emergentist debates: a) complex higher-level entities and properties appear from lower-level elements and constituent parts, some of them being "emergent," others mere "resultants"; b) emergent entities and properties are "unpredictable," i.e. all information concerning their basic conditions cannot predict them in principle; c) the emergent properties are unexplainable and irreducible, which is to say that they are "neither explainable nor reducible in terms of their basal conditions"; $d$ ) the emerging entities or properties should exert some causal efficacy, both at their level and downward, on lower levels.

These topics involve some inconsistencies that still await to be solved. However, it is undisputable that in contemporary debates the notion of emergence represents a lively idea for "many thinkers, with diverse and disparate backgrounds and agendas philosophers, practicing scientists from a variety of scientific fields, and science writers." What makes emergence so attractive is, in Kim's words (2006: 547), an "intriguing philosophical question." Investigating the historical origins and the philosophical background of this notion will help to shed light on its meaning and on the reasons for such interest.

\subsection{James and John Stuart Mill: the Dawn of the Emergentist Tradition}

Emergentism originally developed in the UK in the nineteenth century. John Stuart Mill (1806-1873) is considered the noble father of this tradition, as he systematized an early version of the notion (without using the word), starting from some theoretical insights of his father, James Mill (1773-1836).

In Analysis of the Phenomena of Human Mind (1829), James Mill aimed to provide a psychogenetic foundation for utilitarian ethics, by reducing all the phenomena of human consciousness to an association of representations. Within this associationist framework, Mill claimed that "ideas which have been so often conjoined" seem "to coalesce [...] and out of many to form one idea." This complex idea "appears to be no less simple, than any one of those of which it is compounded" (Mill 1829, I: 68-9). Many of our most general ideas, such as those of "extension," "motion," or "time," have been commonly regarded as simple ideas. On the contrary, they have different origins, being the complex result of a number of simpler elements (ibid.: 70-1). In other words, Mill describes the entities resulting from the aggregation of simpler parts not as the mere sum of those parts, but as novel entities, whose properties appear different from the characteristics of each part taken singularly. 
In the preface to the second edition of Analysis, John Stuart Mill claims that the main task of that work is to "reach the simplest elements which by their combination generate the manifold complexity of our mental states and to assign the laws of those elements": a process akin to "the labour of the chemist to reduce the compound bodies on which he operates [...] to their constituent elements." Therefore, Mill continues, just "as in chemistry, it often happens that the qualities of the separate ingredients of a compound body are not recognizable by us in the apparently different qualities of the compound itself," in the "chemistry of the mind, the compound sentiment that results from the association of former feelings" has "very little resemblance to these constituents of it" (Mill [1829] 1878: viii-x).

In Book III of System of Logic (1843), J. S. Mill provides a generalization of this "chemical" causality and distinguishes it from "mechanical" causation - also called the "Principle of Composition of Causes." According to such principle, which applies to physics and mechanics, the effects produced by every single cause when acting alone combine in a mechanical and deducible way that "is exemplified in all cases in which the joint effect of several causes is identical with the sum of their separate effects" (Mill 1843: 426). Chemical causality, which characterizes chemistry and other scientific fields such as biology, consists in the combination of two different substances to produce "a third substance with properties entirely different from those of either of the two substances separately, or of both of them taken together." These heteropathic (as opposed to homopathic) effects and laws concern phenomena in which the joint effect of causes is heterogeneous with respect to the sum of the separate effects.

Unlike mechanics, chemistry is not a deductive but an experimental science, since "most of the uniformities to which the causes conformed when separate, cease altogether when they are conjoined" and we are not "able to foresee what result will follow from any new combination, until we have tried it by specific experiment" (ibid.: 427). This is even more true for biology, as living phenomena - which are made up of parts similar to those composing inorganic nature - "bear no analogy to any of the effects which would be produced by the action of the component substances considered as mere physical agents." Even if we were to possess perfect knowledge about the ingredients of living bodies, "it is certain that no mere summing up of the separate actions of those elements will ever amount to the action of the living body itself" (ibid.). According to Mill, like chemical and biological laws, which "will never be deducible from the mere laws of the ingredients," mental, social and political phenomena follow the same complex heteropathic patterns (ibid.: 430-2).

As Carlo Sini (1972: 80-1) has highlighted, both J. S. Mill and his father warn us to not confuse the origin of a feeling or representation, with its emerging value. Although water appears to be an original element in nature, it is the chemical result of the composition of gaseous molecules of hydrogen and oxygen, each presenting completely different properties compared to the resulting liquid compound. Similarly, a feeling may emerge as a novel trait, as in the case of pure altruistic generosity, yet derive from the associations of original representations that have nothing to do with altruism and generosity. Once the new property has emerged, however, it presents itself as an entirely independent value, even though it has been discovered to be the complex result of the combination of simpler parts. 


\subsection{British Emergentism and the Pragmatist Tradition}

The System of Logic's section "Of the Composition of Causes" has been defined "as the locus classicus on the notion of emergence" (McLaughlin 1992: 58-9; Nagel 1961: 372). Beyond Mill's analyses, the evolutionist tradition from Darwin and Spencer to Wallace and Haeckel contributed to defining a problematic framework within which mature British emergentist positions were expounded, particularly through the work of Conwy Lloyd Morgan (1852-1936) (cf. Blitz 1992: 46). The main problem for Darwin and the evolutionist tradition was to trace the continuity in dynamic developments from the inorganic world to the organic, from the lower living forms to those on a higher level, and to find a proper place for the emergence of the psychic dimension. Both the framework composed by the evolutionary tradition and the theoretical distinctions drawn by Mill, and subsequently developed by Alexander Bain (1870) and George Henry Lewes (1875), lay the roots of so-called classical British emergentism in the early twentieth century (Stephan 1992: 25). The term "emergent" appeared for the first time, in its technical sense, in Lewes (1875: 412-3), who posed the problem of the continuity of nature, but refuted the traditional idea that the qualities of the whole should be present in its parts and that subsequent events in an evolutionary process should reproduce the properties of antecedent events. Lloyd Morgan adopted the same approach in Emergent Evolution (1923: 5): "Evolution [...] is the name we give to the comprehensive plan of sequence in all natural events. However, the orderly sequence, historically viewed, appears to present, from time to time, something genuinely new. Under what I call emergent evolution stress is laid on this incoming of the new." According to Lloyd Morgan, although there is continuity in the evolution of natural phenomena, it is impossible to predict features that emerge in the context of complex natural systems from their bases in antecedent events. Any emergence is an ontological novelty, not just an epistemic sign of the limits of human knowledge (Blitz 1992: 99).

Further emergentist texts appeared in 1920's Great Britain in addition to Lloyd Morgan's work, such as Space, Time, and Deity (1920) by Samuel Alexander (1859-1938) and The Mind and Its Place in Nature (1925) by Charlie Dunbar Broad (1887-1971). Alexander presented his idea of emergent quality within a broad metaphysicaltheological framework, where he tried to put together the emergence of irreducible qualities with their derivability from rigorous physical-chemical laws. Broad's work, where "the main doctrines of British emergentism receive their most mature formulations" (McLaughlin 1992: 68, 79-89), challenges both the idea of the reducibility of all sciences to physics and the belief that physics is the fundamental form of scientificity. Broad distinguished two different kinds of scientific laws, i.e. intra-ordinal laws, which "connect the properties of aggregates of the same order," and trans-ordinal laws, which characterize the emergence of higher-level properties and relations, insofar as these cannot be deduced before their occurrence in nature (Broad 1925: 77-8).

Although British emergentists did not develop any unitary doctrine, they paved the way for a general emergentist conception based on common assumptions (see McLaughlin 1992: 49-51), which constituted "an alternative to mechanism and vitalism" (Stephan 1992: 25). It is not my intention to reconstruct the different historical and conceptual phases of the emergentist debates in detail. ${ }^{2}$ It suffices to say here that the direction outlined by British emergentism has been advocated in current debates, where - to quote Kim (2006: 548) - "any account of emergence [...] should show 
significant continuity with the concept that the British emergentists of the early 20th century, such as Alexander, Morgan, and Broad, had in mind."

This briefly sketched history of the emergentist tradition shows interesting connections with so-called classical Pragmatism. Ferdinand C. S. Schiller, John Dewey and George Herbert Mead, engaged with emergentism, participated in the debates about it and, in some cases, adopted emergentist terminology. ${ }^{3}$ The notion of emergence is particularly crucial in Mead's Philosophy of the Present (1932), where it is connected with Mead's philosophy of time and with the social character of the human mind, self and language. As Dewey states in his Prefatory Remarks, Mead "took the doctrine of emergence [much more fundamentally] than have most of those who have played with the idea" (Mead 1932 [2002: 33]). In the Introduction to the same text, Arthur E. Murphy writes that "the dominant strain in these lectures" derives from "that philosophy of nature which will no doubt be regarded as the characteristic contribution of the 1920's in Anglo-American philosophy," of which “Alexander's Space, Time and Deity was the pioneer work" (ibid.: 14). The debates on emergentism were so spread among Anglo-American scholars in those years that Murphy regards the notion of "emergence" as a "catchword" of that period (ibid.: 11). This fact is what may have fueled the interest of the classical pragmatists, who actively participated in the debates on the matter and engaged with British emergentism. Conversely, emergentist thinkers such as Lloyd Morgan, Alexander and Broad never considered Pragmatism an interesting philosophy to be examined in relation to their own ideas or used to develop their own thought, except for the work of William James, who was especially appreciated as a psychologist. ${ }^{4}$

It is noteworthy that in the literature regarding the relationship between Pragmatism and emergentism, almost nothing is said about Chauncey Wright (1830-1875), a philosopher close to Mill's and Bain's thought and a crucial figure for the origins of Pragmatism. In particular, he developed a very modern "emergentist" thought, which struck the attention of at least one of the leading British emergentists: Samuel Alexander once told Harold J. Laski that he had "discovered Chauncey Wright through an old bookstall" in London, where he had come across the Philosophical Discussions (see Wright 1877 [PD]), and "was very impressed." ${ }^{5}$ Laski adds in the same letter that Alexander "said that C. W. gave him the impression of the most powerful philosophic mind America had so far produced" (De Wolfe Howe 1953, II: 1327-8). The letter is from 1931 and, unfortunately, there is no indication as to when precisely Alexander encountered the work of Wright. Depending on the date of this encounter (before or after 1920), Wright may or may not have directly influenced Alexander's views about emergence. In any case, as Edward Madden (1964: 75) has noted, Alexander "was more than impressed with it and projected ideas like Wright's into his own full-blown doctrine of emergence." However, Madden continues, "Wright would not have approved this destiny of his little idea, for Alexander even had God as an emergent event."

In the light of these last remarks, I shall now turn my attention to Chauncey Wright, whose emergentist and pragmatic thought deserves to be examined more deeply than it has been done in literature so far. 


\section{Chauncey Wright's Pragmatic Empiricism}

\subsection{A "Forgotten American Philosopher"}

Chauncey Wright $^{6}$ was a North American philosopher, best known today as the " coryphaeus" (CP 5.12) of the Metaphysical Club in Cambridge (Mass.) that around 1872 gave birth to American Pragmatism. Almost all Club members (including William James and Charles S. Peirce) were Wright's old friends and their philosophical thought was deeply influenced by him. With his brilliant epistemological interpretation of the evolutionary theory, Wright can be considered a kind of philosophical intermediary who helped promote that fruitful interaction between pragmatist thought and the Darwinist tradition, which still produces fruitful results both in philosophy and in biology. ${ }^{7}$

Wright was interested at first in William Hamilton's "philosophy of the conditioned," but in the 1960's he converted to the utilitarian and associationist philosophy of Bentham, Bain and the two Mills. Wright was not only an original positivist thinker, who held that the job of philosophy was to unify or organize the sciences, ${ }^{8}$ but he was himself a scientist, equipped with scientific expertise in several fields, from mathematics to botany, from physics to biology. When Darwin's Origin of Species (1859) appeared in the USA, Wright immediately declared himself a staunch Darwinian (LCW: 43) and tried to combine the theoretical cornerstones of the "descent with modification" theory with utilitarian and associationist philosophy. Wright spent more than ten years studying Darwin's theory and he deeply understood its scientific meaning and philosophical relevance, as witnessed by Darwin himself (LCW: 230-1). In his evolutionist papers, in a pure positivist spirit, Wright not only defended the scientific principle of natural selection, but also investigated the logic that inspired Darwin's theory and grasped its theoretical core in a way that was far ahead of his times.

Limits of Natural Selection (1870) is the earliest article on the evolutionary theory and it reviews Alfred R. Wallace's essay by the same title (1870). In this essay and in (1869), Wallace denies that natural selection could ever explain the origin and evolution of the most typical human traits. Wright's criticisms of Wallace's arguments were appreciated by Darwin, who even quoted Wright's work twice in Descent of Man (1871, II: 335, fn.31; 391). Given Darwin's interest, in June 1871 Wright wrote to him, attaching the draft of a second essay, On the Genesis of Species (1871a). In this text too, Wright sided with Darwin, this time against the serious criticism that the British biologist George Mivart had advanced in a text bearing the same title (Mivart 1871). Wright wrote to Darwin that his paper had the "special purpose" of contributing to the evolutionary theory "by placing it in its proper relations to philosophical inquiries in general" (LCW: 230). Darwin answered enthusiastically: "I have hardly ever in my life received an article which has given me so much satisfaction." (LCW: 230). He asked Wright for permission to reprint the paper, at his own expense, as a pamphlet in the UK. That was the beginning of a fruitful correspondence, which lasted until Wright's sudden death, in September 1875.

In 1872, Wright set off on a European journey for a few months and spent two days with the great naturalist and his family in the famous Down House. Here, Wright and Darwin discussed the possibility of dealing with the problem of the evolutionary origin of human self-consciousness and its possible differences with respect to the mind of other 
animals. Together they planned to lay the foundations of a new field of research, called Psychozoölogy (LCW: 248). Wright's most important essay, The Evolution of SelfConsciousness (1873), should have been the inaugural text of that grandiose project (see below, section 4). Unfortunately, Wright died shortly afterwards before completing what, according to Schneider (1946: 351), "if he had lived to develop it, would certainly have been one of the major works in history of American thought."

Except for Madden's work, consisting of two general monographs $(1963,1964)$ and a good number of essays, there are very few pages dedicated to Wright, who today is largely a "forgotten philosopher." Furthermore, those few scholars who have dealt with this philosopher have examined more general aspects of his thought, such as his philosophy of science, his theory of knowledge, and his criticism of metaphysics. Others have just tried to draw a comparison between Wright's philosophy and pragmatist and neo-positivist thought, to determine if this thinker should be regarded as a "founder," "precursor" or "forerunner" of these later philosophical currents. Moreover, most of the very few pages that scholars have devoted to Wright's philosophy of biology were wrote before 1980, and none of them try to analytically compare Wright's Darwinism, including his notion of "novelty," with the epistemological approach prevalent in modern evolutionism and emergentist debates. The attitude of most American scholars towards Wright's work is best expressed by the judgment formulated by Madden (1964: 108), according to whom "we can ignore Wright's biological view [...] because it is philosophically irrelevant."

Despite all this, Wright's reflections on biology and evolution appear very relevant, first of all in order to better understand those aspects that make Wright's philosophy very similar to the emergentist approach and pragmatist attitude. Furthermore, they are of great interest when compared to today's debates on evolution and emergence. Given these reasons, this article aims to examine Wright's evolutionary philosophy and to discuss the application of his "emergentist" approach to the paradigmatic issue of the origin of human self-consciousness.

\subsection{Wright's “Forward-Looking" Empiricism}

Wright began to study The Origin of Species in detail immediately after its publication. However, he published almost nothing on the topic for the subsequent ten years. In the 1960 's, Wright's interest focused mainly on the structure of scientific thought in general.

One of the most significant writings from that period is The Philosophy of Herbert Spencer (1865a), where Wright not only criticizes Spencer's philosophy effectively, but also carries out some interesting analyses of the scientific method in general. "[W]hatever be the origin of the theories of science, whether from a systematic examination of empirical facts by conscious induction, or from the natural biases of the mind," Wright claimed, "the value of these theories can only be tested [...] by an appeal to sensible experience, by deductions from them of consequences which we can confirm by the undoubted testimony of the senses" (PD: 47). In other words, the value of any scientific hypothesis is measured not by looking at the way it comes into being, but by examining the effects produced when it is tested through "concrete experiences of a kind common to all" (LCW: 97). Scientists are interested much more in the consequences of a tested hypothesis than in the method used to obtain it. 
For "traditional" empiricists such as Hume and Mill, all human knowledge derives from sensible experience. This view mainly focuses on the way a scientific idea originates, and it usually results in the prescription that scientific hypotheses should derive from sensible experience. Although Wright defines himself as a follower of the empiricist tradition, he actually reverses its theoretical assumptions by considering the origin of a scientific hypothesis irrelevant: "when and however ideas are developed science cares nothing, for it is only by subsequent tests of sensible experience that ideas are admitted into pandects of science." (PD: 47). Scientific hypotheses should produce a series of predictions that can be tested in sensible experience and lead, in turn, to new observations and truths. Science does not care about the "ontological pedigree or $a$ priori character of a theory," but it is "content to judge it by its performance" (PD: 47), as a "theory which is utilized receives the highest possible certificate of truth" (PD: 51).

The usefulness of a hypothesis appears to be a perfect criterion of verification, insofar as it provides the kind of parameters of certainty that science has been able to apply extensively in the interpretation of natural phenomena. Moreover, Wright states that the notion of utility is related to the "instrumental" use of scientific ideas for "their capacity to enlarge our experience by bringing to notice residual phenomena, and making us observe what we have entirely overlooked" (PD: 55; italics mine). Scientific ideas should prove their value as instruments that, once immersed into experience, are able to extend it and unearth what we had ignored in previous observations. Scientific hypotheses are thus "working ideas, - finders, not merely summaries of truth" (PD: 56; italics mine) and they pragmatically define their value according to their operational capacity to find or produce truths. They are effective working hypotheses leading us to new truths and not simply records or enumerations of observations leading to mere inductive generalizations.

Wright's empiricism differs from British empiricism, as it aims to re-orient the focus of philosophical and scientific inquiry by diverting attention away from the origin of concepts and hypotheses, and directing it to the control of their consequences. While the traditional empiricists were interested in showing that every hypothesis should derive from experience, Wright insisted that the origin of a theory is indifferent, and the key point is to consider the future consequences that hypotheses produce. In other words, Wright turned "classic" empiricism into a new kind of empiricism that we may define as "forward-looking" (see Madden 1964: 124-6).

Although these remarks do not allow us to consider Wright's forward-looking approach as thoroughly pragmatist, they allow us to regard it as an important guideline that strongly points towards a rising pragmatism (Parravicini 2012). An essential element that connotes the so-called "pragmatist revolution" is precisely the move to put the role of "effects" at the center and insist on what "real difference" any idea entails in terms of conceivable consequences as a method to clarify its meaning. ${ }^{10}$ This is the core idea behind Peirce's pragmatic maxim (e.g., CP 5.402) and James' definition of pragmatism, which consists in "the attitude of looking away from first things, principles, 'categories,' supposed necessities; and of looking towards the last things, fruits, consequences, facts" (James 1978: 32).

Furthermore, Wright's definition of scientific ideas as "working hypotheses" is a very pragmatist one (see Pearce 2020: ch.7). Dewey used almost the same Wright's words to describe the theoretical shift leading from classical empiricism to pragmatist instrumentalism, which 
presents itself as an extension of historical empiricism with this fundamental difference, that it does not insist upon antecedent phenomena but upon consequent phenomena [...] and this change in point of view is almost revolutionary in its consequences. An empiricism which is content with repeating facts already past has no place for possibility and for liberty. It cannot find room for general conceptions or ideas, at least no more than to consider them as summaries or records. But when we take the point of view of pragmatism we see that general ideas have a very different role to play [...]. They are the bases for organizing future observations and experiences. (Dewey 1925b: 365-6; italics mine)

Despite these similarities, Wright never generalized his epistemological approach to scientific hypotheses by developing it into a pragmatist theory. Nevertheless, Wright's forward-looking strategy could be considered an incipient pragmatist conception, probably emerging from the frequent and prolonged philosophical discussions that Wright entertained from the 1960's with Peirce, James and his other friends at the Metaphysical Club.

As we will see in the next section, the philosophical move towards a forward-looking empiricism is closely related to Wright's examination of Darwin's evolutionary theory.

\section{Evolution and the Notion of "Novelty"}

\subsection{Wright Between Darwinism and Pragmatism}

The "history of evolutionism is intimately linked with the genesis of Pragmatism" (Wiener 1949: 30). Since the Metaphysical Club period, Wright, Peirce, James and the other companions perceived the epochal importance of the evolutionary theory and investigated its logic through their peculiar pragmatic approach, which in turn was fueled by Darwin's perspective. Later, Dewey and Mead further strengthened that powerful bond holding together the evolutionary perspective and the pragmatist approach.

Wright is "our key figure" to understand the link between evolutionism and Pragmatism in all of its different forms (Wiener 1949: 33). In two essays published in the very years of the Metaphysical Club meetings, Wright (1871a, 1872) defended Darwin's theory against Mivart's attacks, at the same time reflecting on some philosophical aspects of the evolutionary theory. As regards Darwin's use of "accidental variation," Wright clarifies that "accidental" does not refer to pure chance, but to the incapacity to foresee the occurrence of variations due to the presence of an inextricable interplay of factors (PD: 130-3). The word "chance" reflects the occurrence of complex phenomena, which originate from a series of intertwined causal chains that we are not able to disentangle for the purpose of prediction (PD: 173-4).

Regarding this aspect, Wright pointed to a fundamental feature of Darwin's theory, namely that the causal level of variations and that of natural selection should be considered independent from each other. This means that individual variations, which are "constant and normal in a race," have to be regarded as "accidentally related to the advantages that come from them." Similarly, we say, "a tendril, or a tentacle [...] is accidentally related to the object it succeeds in finding" or "that it was by 'accident' that a certain tendril was put forth so as to fulfill its function, and clasp the particular object by which it supports the vine." In other words, "The search was and continues to be, normal and general, it is the particular success only that is accidental" (PD: 143-4; italics mine). 
Wright identifies two distinct meanings in Darwin's use of "accident" and "chance" in relation to variations. In a sense, the latter are called "accidental" as they cannot be predicted, owing to human ignorance about the causes producing them. Even today, scientists believe that genetic mutations are produced by specific causes (e.g., radiations, chemical mutagens, etc.), but they consider it useless and almost impossible to identify the precise factors that, from time to time, produce mutations in certain DNA portions within an infinitesimal timeframe.

The second, and more interesting, meaning of the word "chance" regards the fact that variations are accidental in relation to their "particular success," i.e. to the (positive, negative or irrelevant) consequences they have for organic forms. In other words, the reasons for the origin of given variations are largely independent of the function or value that these variations possess, once they have entered in the dynamic context of environmental relationships, in which every variation is subject to the severe sieve of natural selection (Parravicini 2012: 148-9; Pievani 2015: 2). ${ }^{11}$ Variations are fundamental for the evolutionary process, because they provide the fuel without which no selective process could take place. Nevertheless, the origin of variations is attributable to a range of causes independent of environmental conditions (i.e., "selective pressures") and of any results in terms of phenotype performances. Such contingent interweaving of different causal levels leads to the differential survival (i.e., natural selection) of some organisms compared to others, statistically based on the advantage produced by certain variations with respect to others. This is the reason why Wright states that "the origin of that which through service to life has been preserved, is to this process arbitrary, indifferent, accidental (in the logical sense of this word), or non-essential. This origin has no part in the process." (PD: 252). From Wright's point of view, it is not important to know precisely what causes have given rise to a certain "accidental" variation, but to examine the actual consequences of a variation.

In the wake of Wright's analyses, we may apply to Darwinian explanations Mill's warning about confusing the origin of an idea with its emerging value (see par.1.2). In other words, the causes of the origin of variations should not be confused with the selected effects related to their value for life. American paleontologist Stephen Jay Gould, who warned us to keep separate the reasons for the origin of structures or behaviors from their current meaning for life, recently reaffirmed the same admonition (Gould 2002: ch. XI).

Wright claims that the process subtended by the misleading term "evolution" (PD: 199) does not refer, as traditionally believed, to an "aprioristic" process involving a "relation of beginning and end - a development" (Wright 1866: 725). Evolution is not an unfolding of properties already implicitly present from the beginning or a movement directed towards a predetermined path, similarly to "an epic poem" that is divided into "a beginning, a middle, and an end" (PD: 73-4). Darwin has generated a radical break with all those cosmic-evolutionary views "which make the cause to be engendered by the effect" (PD: 101). There is no immanent design, but only an accumulation of variations selected for reasons that are independent from those for which they arose. There is no linear or unidirectional movement, but a process of sedimentations and additions (PD: 262) in which the preserved variations contingently constrain and influence the direction of the process.

In such an evolutionary process, where the effects of the contingent causal plots become visible only in retrospect, any variation is comparable to a sort of hypothesis that 
can only be validated as useful or discarded as irrelevant or harmful in the future. All variations, however they may have arisen, "are beginnings, not ends; potentialities, not finalities; candidates for office, not appointments due to their inherent goodness" (Chambliss 1960: 146).

A clear analogy emerges here between Wright's interpretation of Darwin's evolutionary theory and the ratio of effects characterizing what we have called "forward-looking" empiricism (par. 2.2). According to this forward-looking logic, the value of a scientific hypothesis is tested through the consequences that follow from its implementation in sensible experience. In the same way, the value of any organic variation is measured once it has passed through the sieve of natural selection, based on the consequences it has generated for the life of organisms. Max H. Fisch (1966: 15) perfectly summed up this analogy:

The experimental theory of knowledge [i.e., the pragmatic approach] owed its prevalence among us in part to Darwinian analogies. It is but a more general form of the philosophy of science which makes much of hypothesis, prediction and experiment, and make's little of Bacon's and Mill's methods of induction. The analogies lie between the hypothesis and the spontaneous variation on the one hand, and between the experiment and natural selection on the other [...]. What tests a scientific hypothesis is future experiment, not the observations from which it sprang.

The value of an organic variation is selectively tested in terms of its usefulness in the struggle for life, just as the "cash value" (James 1978: 35, 117) of an idea is tested in terms of the conceivable consequences it generates in experience. In conclusion, this kind of forward-looking approach developed by Wright can be considered a crucial aspect tightly linking together Darwinism and pragmatism.

\subsection{Evolutionary Novelties}

The notion of novelty is crucial in Wright's evolutionary philosophy and closely related to the classical concept of emergence. Wright tried to combine Mill's associationist framework (included his emergentist analyses - see par. 1.2) with his own original interpretation of Darwin's theory. In such a framework, the notion of "novelty" is the key concept through which Wright tried to understand the deep nature of living phenomena, which he considered "a higher form of chemistry" (LCW: 204).

In a letter dated 22 March 1870, Wright declares that the apparently regular patterns of life are the result of infinitely complicated plots made of different causal lines giving rise to a self-conserving equilibrium. Life builds a contingent multi-level order out of the physical and chemical laws of the universe, but this "order" is "an entirely exceptional and precarious state of things" (LCW: 177). Living forms ultimately show the "same mixed character of regularity and apparent accident" as all other natural phenomena, which is to say the same "infinitely complex and confused movement [...] of action and counteraction in the balanced forces from which they spring" (PD: 5). Nevertheless, Wright considered the biological sciences to be radically different from other scientific fields, like mechanical physics or astronomy. Against Mivart, who considered biology "essentially a branch of physical science," Wright defended the autonomy of living phenomena, which show their own peculiar (we might say emergent) patterns and processes - like natural selection - which are "operative in nature but not reducible to the laws of physical science." ${ }^{12}$ 
The accidental features that combine with the linear operation of physical-mechanical laws pervade the natural world and show all their evidence in the phenomena of life. Wright clearly showed the complete reversal operated by Darwinian logic with respect to any "aprioristic" view of natural processes (see par.3.1). Each new event or combination of events, like a variation in some trait of a given organism, may produce unpredictable consequences in the economy of life and modify the course of the evolutionary process. As we began to see in the previous paragraph, according to Wright evolutionary novelties emerge at the crossroad between the causal plots that produce any given variation, and those occurring at the different level of ecological/ environmental interactions, in which the same emerging variation concretely operates.

In such a multi-level evolutionary framework, the occurrence of a new trait may take the form of an authentic novelty whether it exhibits characters different and unpredictable from those of the antecedent conditions that give rise to it. In the wake of Mill's analyses, Wright (1873) argues that

Experimental science, as in chemistry, is full of examples of the discovery of new properties or new powers, which, so far as the conditions of their appearance were previously known, did not follow from antecedent conditions, except in an incidental manner, - that is, in a manner not then foreseen to be involved in them; and these effects became afterwards predictable from what had become known to be their antecedent conditions only by the empirical laws of rules which inductive experimentation had established. (PD: 201)

Unpredictable novelties can always emerge from a set of antecedent conditions that have characteristics qualitatively different from what emerges from their combination. In Wright's view, the natural world is a "great alchemic experiment" which employs "all the influences of nature and all the ages of the world" (PD: 167). In such a great "work of creative power," any accidental combination of factors could open up the possibility of the emergence of new qualities.

Wright specifies that any "really new power in nature" is "only involved potentially in previous phenomena," as in the case of "the power of flight in the first birds" (PD: 200). However, the term "potentially" here does not refer to a pre-formational process of " evolutio,"13 i.e. to a process in which a latent potentiality is already involved and progressively unfolds. On the contrary, Wright understands novelty as an authentic and unexpected event (cf. Madden 1964: 74-6), meaning that it cannot be rationally attributed to potentialities contained in acknowledged antecedent conditions prior to its first empirical occurrence. In other words, before the empirical experimentation has been actually conducted and registered, it is not possible in principle to rationally foresee the occurrence of the novel fact, or explain whether it is "involved potentially" in a set of given causes or conditions. Indeed, it is the inductive experimentation of the novelty, the registration of its empirically verified effects, that retroactively enlightens and establishes a-posteriori the "incidental" causes or antecedent conditions of those novel effects, which from then on become predictable.

Wright clarifies that we should not posit a supernatural event behind the "appearance of a really new power in nature." Such events, although they are not deducible before their first occurrence, are "still natural events," where the word "nature" means "those kinds of effects which, though they may have appeared but once in the whole history of the world, yet appear dependent on conjunctions of causes which would always be followed by them." One experiment could be enough to establish such causal dependence, "though the particular law so determined is a wholly empirical one." 
"Scientific research implies the potential existence of the natures, classes, or kinds of effects which experiment brings to light through instances, and for which it also determines, in accordance with inductive methods, the previously unknown conditions of their appearance." (PD: 202). The novelty and the conditions of its occurrence can thus be explained only in retrospect, after it has already happened at least one time.

Wright's reflections about novelty, on the one hand, appear to be undoubtedly undergirded by the peculiar scientific positivism and forward-looking empiricism developed by the American thinker from the 1960's. On the other hand, they closely recall the reflections made by classical British emergentists, who also emphasized the unpredictable aspects of novel entities emerging from their composing parts or starting conditions (Stephan 1992). Like Wright, they did not deny the possibility, based on experience, of making predictions about the nature of novel properties. They only denied the possibility of deducing emergent properties from their basic conditions and before having registered in the experience what these conditions actually bring about when they come together (Zhok 2011: 62). Both Wright and classical emergentism agree that any novelty is thus unpredictable in principle before it occurs and can only be postdictively reconstructed starting from the effects, in order to infer the antecedent hypothetical conditions. ${ }^{14}$

Wright's analyses fit well even with some modern influential biological views. One of the most eminent biologists of the 19th century, Ernst Mayr (1982: 53), uses the words of Herbert A. Simon to define life phenomena as complex systems where "the whole is more than the sum of the parts [...] in the important pragmatic sense that, given the properties of the parts and the laws of their interaction, it is not a trivial matter to infer the properties of the whole." There are "two reasons why biological events are so often unpredictable: the great complexity of biological systems and the frequency at which unexpected novelties emerge at higher hierarchical levels [...]. These factors do not weaken the principle of causality, conceived in a 'postdictive' sense." (Ibid.: 58). Within this very Wrightian framework, Mayr mentions another core element of Wright's thought, namely the idea of the "randomness of an event with respect to its significance." Quoting Karl Popper and Lloyd Morgan, Mayr concludes that "we live in a universe of emergent novelty," and that "such emergence is quite universal" (ibid.: 63).

\section{Exaptive Emergent Novelties: Human Self- Consciousness}

\subsection{Wright and the Evolution of Self-Consciousness}

The emergence of the human mind is a key issue both for the emergentist debate and for the current research in the evolutionary field. In his major work, Wright (1873) describes the origin of human self-consciousness as a paradigmatic example of an authentic emergent novelty, i.e. a "really new power in nature." Wright states that "no act of self-consciousness, however elementary, may have been realized before man's first self-conscious act in animal world" (PD: 200-1). Human self-consciousness is a real novelty, unpredictable and not deducible before its occurrence. The new trait is recognized to be potentially involved in pre-existing powers or causes only after its appearance in the animal world, in the sense explained in the previous section. Wright provides an interesting image to further clarify this point: 
The derivation of this power, supposing it to have been observed by a finite angelic (not animal) intelligence, could not have been foreseen to be involved in the mental causes, on the conjunction of which it might, nevertheless, have been seen to depend. The angelic observation would have been a purely empirical one. The possibility of a subsequent analysis of these causes by the self-conscious animal himself, which would afford an explanation of their agency, by referring it to a rational combination of simpler elements in them, would not alter the case to the angelic intelligence, just as a rational explanation of flight could not be reached by such an intelligence as a consequence of known mechanical laws; since these laws are also animal conditions, or rather are more general and material ones, of which our angelic, spherical intelligence is not supposed to have had any experience. Its observation of the conditions of animal flight would thus also be empirical. (PD: 201)

Similarly to what the British emergentists will claim about fifty years later, Wright is arguing that the emergence of the earliest acts of self-consciousness, such as those of other living structures or capacities (e.g., flight), is rationally explainable through a series of antecedent conditions or causes that nonetheless may reveal features different from, and incidental to, the novel trait resulting from them. However, before the new emergent quality actually occurs, no prediction of it is possible, nor any rational explanation in terms of antecedents or conditions of possibility, even if we imagine a superhuman angelic intelligence analyzing the entire process. In other words, a superhuman intelligence of this sort would not have been able to rationally foresee the emergence of the novel power of human self-consciousness through the mere observation or analysis of its mental antecedents or composing traits. As noted in the previous section (\$3.2), it is in principle impossible to deduce the emergence of a novelty (e.g., human self-consciousness or flight) before any actual empirical observation of it, and only through a mere rational analysis of its composing parts or antecedent conditions. Even an angelic intelligence needs to empirically experience the novelty in order to reconstruct the antecedent conditions of its emergence.

Both according to Wright and to classical emergentism, it is not crucial to admit that the emergent novelty is contingently unpredictable or unexplainable because of the relative limits of scientific knowledge at a given time. What it is fundamental to acknowledge for them is that the emergent properties or entities are in principle and essentially unpredictable and non-deducible (Zhok 2011: 53-69). However, such unpredictability does not entail a complete elusiveness of the emergent novelty from a rational point of view. Far from admitting a kind of creatio continua or arbitrary unpredictability, the emergentist thinker, like Wright, claims that the emergent novelty should display a constant and regular link with its material conditions or basic components. Nonetheless, both the constraining link and the supervenience of the emergent novelty cannot be foreseen in principle before the emergent property actually manifests itself. Once the emergence manifests itself empirically, it should be possible to use the link with its material base to foresee the appearance of the same emerging properties on future occasions.

Furthermore, Wright argues that the material conditions for the emergence of the human mind are different from their result. Mental events belong to a new class of phenomena, being a qualitative emergence that cannot be wholly deconstructed into physical atoms, neuronal movements or cerebral areas. Mental events may be fully conditioned by physical-cerebral processes, but the former are not entirely reducible to the latter. Although the result is not reducible to its antecedent conditions, the process 
remains continuous from the point of view of natural laws, and rationally explainable a-posteriori.

As Wright (1870) noted, it is worth spending intellectual energy to carry out empirical research on "the special physical antecedents, concomitants, and consequents of special sensations" or on the relations of co-presence between physical and mental realities.

[s] uch researches may succeed in reducing all other facts of actual experience, all our knowledge of nature, and all our thoughts and emotions to intelligible modifications of these simple and fundamental existences; but the attempt to reduce sensation to anything but sensation is as gratuitous and as devoid of any suggestion or guidance of experience [...]. In one sense material phenomena, or physical objective states, are causes or effects of sensations, bearing as they do the invariable relations to them of antecedents, or concomitants, or consequents. But these are essentially empirical relations, explicable perhaps by more and more generalized empirical laws, but approaching in this way never one step nearer to an explanation of material conditions by mental laws, or of mental natures by the forces of matter. Matter and mind co-exist. There are no scientific principles by which either can be determined to be the cause of the other. (PD: 117-8)

In conclusion, according to Wright, the relation between mind and brain is not a causeeffect relation, but one between two co-existent yet different dimensions, each with its own irreducible specificity. In other words, mind is an irreducible emergent effect, not an epiphenomenon of brain processes.

\subsection{The Emergence of Self-Consciousness as the "New Use of Old Powers"}

In the evolutionary framework described by Wright, the principle of "new uses" plays a crucial role, closely related to the notion of "novelty." As Wright (1873) argues,

new uses of old powers arise discontinuously both in the bodily and mental natures of the animal, and in its individual developments, as well as in the development of its race, although, at their rise, these uses are small and of the smallest importance to life. They seem merged in the powers to which they are incident, and seem also merged in the special purposes or functions in which, however, they really have no part, and which are no parts of them. Their services or functions in life, though realized only incidentally at first, and in the feeblest degree, are just as distinct as they afterwards come to appear in their fullest development. The new uses are related to old powers only as accidents, so far as the special services of the older powers are concerned [...]. (PD:199-200)

The principle of "new uses of old powers," sometimes called the "principle of uses," entails the aforementioned idea that each variation is accidental as far as purpose is concerned (see section 3.1). Any trait may embody a plurality of new uses that could unexpectedly emerge in consequence of changes in the ecological-environmental niche. A trait that originally emerged in relation to certain uses may be later co-opted for further functions that are accidentally involved, or the same function may be realized by different traits that evolved for different uses. In Wright's words,

many mental as well as bodily powers thus have mixed natures, or independent uses; as, for example, the powers of the voice to call and allure, to warn and repel, and its uses in music and language; or the numerous uses of the human hand in services of strength and dexterity. And, on the contrary, the same uses are, in some cases, realized by independent organs as, for example, respiration in water and in the air by gills and lungs, or flight by means of fins, feathers, and webs. (PD: 200) 
Wright provides many other examples of his principle. The incipient rattle of the rattlesnake, the expanding neck of the cobra (PD: 158-9) and the long neck of the giraffe (PD: 151-2) could all serve many different functions. Wright clarifies that "The use which may be presumed in general to govern selection is a combination, with various degrees of importance, of all the actual uses in a structure" (PD: 191); it is "the combination of all the uses that are of importance to the preservation of life." Therefore, to suppose that one of these uses was of little importance in the incipient stage of a structure does not rule out "the existence of uses more important which would afford grounds of advantage and competition in the struggle for life" (PD: 193).

Wright's idea that the evolutionary process is based on a reserve of structural and functional redundancies makes this process more similar to one of tinkering, which accidentally patches up old structures for new uses, rather than to the activity of an engineer, who optimally designs and adapts every trait from the outset. ${ }^{15}$ In addition, the principle of new uses strengthens the admonition that the causes of variations should not be confused with their value for life (see section 3.1). As the principle of uses predicts that a trait which originally emerged in relation to certain uses or for no use at all may later be co-opted for different functions, it also implicitly warns us not to confuse the reasons for the origin of a given structure with the current uses of it.

In the light of all this, it is not hard to see a close similarity between Wright's principle of uses and the evolutionary process called exaptation, in the wake of Gould \& Vrba (1982)'s proposal. ${ }^{16}$ This principle plays a crucial role among modern evolutionary biologists, for whom the warning to keep the historical origin of a given feature distinct from its current use is as valid today as it ever was, being an antidote to any teleological or "adaptationist" interpretation.

Wright (1870) began to propose an application of his principle of uses to contrast Wallace's argument on the impossibility for natural selection to account for the origin of the most typical human traits, both mental and physical. Later, Wright made extensive use of the same principle in an essay on phyllotaxis (Wright 1871b) and in two reviews (Wright 1871a, 1872) of Mivart's Genesis of Species in order to defend Darwin's theory, especially against those invoking "the incompetency of natural selection to account for the incipient stages of useful structures" (Mivart 1871: ch.2). It is noteworthy that the above-mentioned articles (except Wright 1872) appeared before the publication of the Origin's sixth edition, where Darwin added an entire chapter (the seventh) to refute objections against natural selection and used, against Mivart, arguments very similar to Wright's. ${ }^{17}$ Even in his last letter to Darwin (Feb. 1875), Wright emphasized the central role of the "plurality of uses" principle within the architecture of evolutionary theory, whereas Darwin regarded it as a mere scholium (LCW: 336).

In The Evolution of Self-Consciousness (1873), Wright applied the principle of uses in order to rethink the origin of human mind and language, thus largely anticipating contemporary scientists' proposal to apply the exaptive mechanism as a means to account for the emergence of modern human cognition. ${ }^{18}$ According to Wright, a trait or a power which originated in relation to certain functions may be coopted for different uses. In Gould's words (2002: 1226), the wing may have been selected for reasons different from flight, i.e., for thermo-regulative functions or for no function at all, and then coopted for flight. Similarly, to Wright, the human mind evolved through new uses of some old powers, namely through a new capacity to remember and 
manipulate signs. In Wright's analysis, "internal images or successions of images which are the representative imaginations of objects and their relations" are "effective as notative, directive or guiding elements in thought" not only for humans, in whom they are supplemented by names, but also in "dumb animals," for which they serve as "instruments of thought in judgement and reasoning" (PD: 208). However, even in the most intelligent animals, those images are so "vague and feeble" that "they cannot be associated with outward signs in such a manner as to make these distinctly appear as substitutes, or signs equivalent to them" (PD: 209). Those images that act as signs "in governing trains of thought and reasoning," in the animal mind are immediately forgotten, "merged in the things signified, like stars in the light of the sun," as the outward signs are much more vivid.

The emergence of the human mind is the consequence of a new use of those internal images, made possible by "an extension of the range in powers of memory, or in revived impressions." Selected variations in the mental powers of proto-humans were the conditions for the emergence of human intelligence, allowing it "to fix its attention on a vivid outward sign, without losing sight of [...] an image or revived impression" which serves as "a sign of the same thing, or the same event" (PD: 210; italics mine). For the first time, internal images were recognized as "representative images," namely as signs for outward objects and external images. This new use opened up the possibility of recognizing representative images as "my thoughts, or our thoughts, or as phenomena of the mind" (PD: 216). They now came to be recognized as general signs that could be intentionally used even in the absence of the corresponding impressions. "This would plant the germ of the distinctively human form of self-consciousness." (PD: 210).

It is not my aim here to explain Wright's hypothesis on the origin of human selfconsciousness in detail. It is sufficient to emphasize the importance of Wright's evolutionary logic of effects and the crucial role played by the idea of emergent novelties and new uses. A gradual and continuous sedimentation of small accidental variations in a series of traits, selected in relation to some favorable reasons and functions, may give rise to qualitatively different and unexpected emergent consequences. In the case of human consciousness, a combination of different factors such as a gradual strengthening of memory and attention, a gradual encephalization, and a continuous development of phonatory structures - may have set the bases for a functional shift in the proto-human mind towards a new use of internal images as signs. In Wright's words, "reflection is a distinct faculty, and though, perhaps, not peculiar to man, is in him so prominent and marked in its effects on the development of the individual mind, that it may be regarded as his most essential and elementary distinction in kind. For differences of degrees in causes may make differences of kinds in effects." (PD: 217).

The principle of uses thus has a strategic function when integrated with the notion of "novelty," as it can bring together in a coherent way the discontinuous event of the novelty, in the form of a functional shift, and the continuous tissue of the evolutionary process, i.e. the continuity of the evolving bodily traits from which the new use emerges. As regards human self-consciousness, a small functional shift within the continuous tissue of the bodily structure may have accidentally triggered the emergence of "a really new power in nature" that no examination of the antecedent conditions could ever have foreseen, before the actual manifestation of the power itself. 
Furthermore, in Wright's view, every emerging novelty or new use can produce "incidental developments" that may modify the evolutionary trajectory, implicitly suggesting the possibility of a kind of downward causation. This is another aspect that brings Wright very close to the British emergentists, and to Lloyd Morgan above all. For both thinkers, the emergent novelty may generate downward consequences that change "the way pre-existent events run their course," thereby causing them to be "altered in the context of that new kind of relatedness" (El Hani \& Pihlström 2002: 2-3). The emergence of the human self-consciousness is a paradigmatic example, owing to the significant evolutionary effects generated after its emergence, such as, in Wright's words, "the traditions of language, with all the knowledge, histories, arts and sciences involved and embodied in them." All these consequences that have irreversibly modified the course of evolution "are developments incidental [...] to the existence and exercise of self-consciousness [...] and were added to them rather than evolved from them" (PD: 262). This process, which is far from constituting some kind of instructive or pre-formational development, ${ }^{19}$ clearly exemplifies what Wright means by "novelty," i.e. an inedited emergence from a combination of causes which produces incidental side effects that can in turn change the evolutionary trajectory.

\section{Neutral Monism and Pragmatic Realism}

One of the most important side effects of the emergence of human self-consciousness is the ability to distinguish between "inner" and "outward" phenomena. As Wright argues, such a distinction between mental and external phenomena is the product of inferences on signs, not a magical "intuitive distinction," as supposed by "most metaphysicians" (PD: 219). Before a phenomenon is judged to be "internal" or "external," "real" or "mental," it is neutral and completely indistinct with respect to those divisions. The ability of attribution, Wright claims, "comes either from the direct observation of our progenitors, or, possibly, through the natural selection, of them; that is, possibly through the survival of those who rightly divided the worlds, and did not often mistake a real danger from a dream" (PD: 231).

The human mind classifies experiences for pragmatic reasons of survival, and in doing so it creates the distinction between "self" and "world," between "inside" and "outside," between "mind" and "body." These distinctions are not already given a priori, as the Cartesians thought, but are consequences of the evolutionary process. At the outset, when a phenomenon is still "unattributed" to the "internal" or "external" world, there is neutrality between the two worlds. This is the reason why Wright claimed that "matter and mind co-exist" (see section 4.1).

Madden defined Wright's position as "neutral monism" (Madden 1954, 1963: 128-42) and regarded it as being very similar to James' idea of "pure experience," according to which the phenomena of consciousness are originally neutral and assume a functionaladaptive role through experience. ${ }^{20}$

Wright's view, which is critical of any form of dualism, natural realism or idealism, is reminiscent of the "pragmatic realism" characterizing the subsequent pragmatist philosophy, according to which something is real when it produces effects on us or somewhere. In an article devoted to Masson's Recent British Philosophy (1866), Wright argued that 
A question is closed when we have a knowledge precluding the possibility of evidence to the contrary, or where we are ignorant beyond the possibility of enlightenment. An ontological knowledge of the supernatural, or even of the natural - that is, a knowledge of anything existing by itself and independently of its effects on us - is, according to the experiential philosophy, a closed question. (PD: 348; italics mine)

This position, which is foundational to Wright's peculiar positivism (cf. Pearce 2015: 448-9), is further clarified in a letter to Francis E. Abbott (1867), where Wright states that what something is actually coincides with the phenomenon, namely with what is knowable, and that, conversely, the knowable is everything that is: "To say the phenomena are all that exists is to say that, in knowing phenomena, we know all the natures that exist." (LCW: 131). In other words, being is its effects and coincides with what is knowable, similarly to what Peirce would argue shortly thereafter in Questions Concerning Certain Faculties Claimed for Man (1868).

What Wright claims concerning the crucial importance of effects for the definition of what really exists or what is actually knowable perfectly fits with the above-mentioned "forward-looking empiricism" (see section 2.2) and is another crucial clue that brings Wright's thought closer to the genuine sense of "the pragmatist revolution."

Traces of "pragmatic realism" emerge again when Wright, in his essay on Spencer, defines the meaning of scientific concepts in terms of their effective use and of their sensible effects in concrete experience: "Chemical forces are not mathematically comprehended, and are therefore utterly unknown, save in their effects, and their laws are unknown, save in the observed invariable orders of these effects" (PD: 79; italics mine). The same idea is expressed in Wright (1865b): "Do we know more of the phenomenon, viewed without reference to other phenomena, by saying it is produced by force? Certainly not. All we know or see is the effect; we do not see force, - we see motion or moving matter." ${ }^{21}$

These pragmatic elements connoting Wright's "forward-looking empiricism" seem particularly significant if we consider that, according to El-Hani and Pihlström (2002: 33), a form of pragmatic realism can provide a key theoretical contribution to better understand the notion of "emergence" and to overcome the theoretical problems that are involved in "the purely ontological, metaphysically realist treatment of emergence typical of most contemporary approaches." El-Hani and Pihlström (2002: 22, 24-5) claim that a "pragmatic realism," which is "inherently pluralistic and anti-reductionistic," supports the idea that "ontology is not clearly separable from epistemology" and that "emergent properties are not metaphysically real independently of our practices of inquiry but gain their ontological status from the practice-laden ontological commitments we make." Therefore, pragmatism (and, we may add, Wright's forwardlooking empiricism) "might serve as a background philosophical framework supporting a 'mildly realist' interpretation of the reality of [...] emergent properties" as dependent "on human ontological classifications, although we should, in the spirit of reasonable naturalism, say that they have (diachronically) 'emerged' out of the non-human world."

\section{Concluding Remarks}

The notions of "novelty" and "emergence" have been examined through the original lens of Wright's pragmatic and evolutionary philosophy. Wright never used the term 
"emergence," which was introduced in its technical sense by Lewes (1875) in the year of Wright's death. However, in the light of what has emerged here, Wright's reference both to living phenomena in terms of novelties unexpectedly appearing in the evolutionary process, and to the human mind as an evolutionary emergent novelty, represents much more than "a kind of embryonic emergentist view," as Madden (1964: 74) wrote. Wright's reflections, combining Mill's emergentism and Darwin's evolutionism, project his thought into the future, since they prove to be very close to later developments in classical pragmatist thought and British emergentism, and even to some more recent perspectives in evolutionary biology.

As Brioschi (2019: 2.2) has recently noted, the ideas of irreducible "novelty" and of "mind in evolution" represent two key traits that classical pragmatism shares with British emergentism. Both these notions have been shown to lie at the core of Wright's philosophical analyses.

Significantly, Samuel Alexander "was very impressed" by Wright's thought and expressed ideas very similar to Wright's with his 1920 doctrine of emergence (see par. 1.3). On the pragmatist front, beyond James and Peirce, whose philosophical views were directly influenced by Wright's thought, an emergentist position in many respects close to Wright's was expressed by Mead, especially in The Philosophy of the Present. ${ }^{22}$ Furthermore, Mead (1934) adopted an idea similar to Wright's one of "new uses of old powers" in describing the emergence of the human "mind" as the outcome of a new use of the vocal gesture.

Wright's conception of "novelty," incorporated both into an original evolutionary view and into an embryonic pragmatist framework, radically transformed Mill's emergentism. It is very likely that Wright borrowed his own emergentist framework from the two Mills and the associationist tradition, which provided a useful key to interpret Wright's conception of living processes. However, as Sini (1972: 84-5) pointed out, the associationist notion of "analysis" is a static procedure that can still throw light on a mosaic of factors, but which "cannot grasp or foresee the whole of this mosaic, neither for what refers to the past, nor for what concerns the future." In the light of these words, we may claim that Wright was able to transfer the idea of emergent novelty from the static conceptual framework of associationism to the much more dynamic Darwinian evolutionary thought. In Wright's eyes, the "descent with modification" theory represented an element capable of transforming the principle of utility into a valid criterion for the genealogical reconstruction of the constitution of complex elements. In this sense, I fully agree with Peirce, who once told Wright that Darwin's "ideas of development had more vitality" than Mill's conceptions, and that this "little vine clinging to the tree of Associationalism, [...] after a time [...] would inevitably kill the tree" (CP 5.64, 1903).

In conclusion, Wright's thought can be interpreted as a crucial landmark not only to enlighten the strategic connection between Darwinism and pragmatism, but also to better understand the key transition from associationist interpretations of emergence to later philosophical and biological debates (from British emergentism onwards). Modern discussions on emergence are no longer nourished by the "Associationist tree," but rather - as Peirce correctly predicted - by Darwin's original "little vine." This has grown into a very solid tree, supporting the entire research program of the biological sciences, nourishing a wide variety of other scientific disciplines, and constituting for 
philosophy - even today - "the greatest precipitant of new methods, new intentions, new problems” (Dewey 1910: 19).

\title{
BIBLIOGRAPHY
}

\author{
Abbreviations \\ CP x.y = PEIRCE Charles S., (1931-1958), Collected Papers, volume x, paragraph y. \\ PD:X = WRIGHT Chauncey, $(1877$ [2000,1]), Philosophical Discussions, page $\mathrm{x}$. \\ LCW:X = WRIGHT Chauncey, $(1878[2000,2])$, The letters of Chauncey Wright, page $\mathrm{x}$. \\ ALEXANDER Samuel, (1920), Space, Time, and Deity, London, Macmillan.
}

BAAS Nils A. \& Claus EMmeChe, (1997), “On Emergence and Explanation,” Intellectica 25, 67-83.

BAGGIO Guido, (2015), La mente bio-sociale. Filosofia e psicologia in G. H. Mead, Pisa, ETS.

BAGGIO Guido, (2019), “Evolution and Emergence. Conwy Lloyd Morgan and George Herbert

Mead," European Journal of Pragmatism and American Philosophy, XI (2).

BAIN Alexander, (1870), Logic, Books II-III, London, Longmans, Green, Beader \& Dyer.

BEDAU Mark A. \& Paul HUMPHREYS, (2008), Emergence: Contemporary Readings in Philosophy and Science, Cambridge (Mass), MIT Press.

BECKERMANN Ansgar, FLOHR Ans, \& KIM Jaegwon (eds), (1992), Emergence or Reduction? Essays on the Prospects of Nonreductive Physicalism, Berlin-New York, De Gruyter.

BELLA Michela, (2019), Ontology after Philosophical Psychology. The Continuity of Consciousness in William James's Philosophy of Mind, Lanham, Lexington.

BENNETT-HUNTER Guy, (2015), “Emergence, Emergentism, Pragmatism," Religion and Science, 13 (3), 305-24.

BLITZ David, (1992), Emergent Evolution: Qualitative Novelty and the Levels of Reality, Dordrecht, Kluwer Academic Publisher.

BRIOSCHI Maria Regina, (2013), “A Niche for Subjectivity: Emergence and Process According to S. Alexander and A. N. Whitehead," Nóema, 4 (2), 81-103.

BRIOSCHI Maria Regina, (2019), "Does Continuity Allow for Emergence? An Emergentist Reading of Peirce's Evolutionary Thought," European Journal of Pragmatism and American Philosophy, XI (2). BROAD Charlie Dunbar, (1925), The Mind and Its Place in Nature, London, Routledge and Kegan Paul. BUNGE Mario, (2003), Emergence and Convergence: Qualitative Novelty and the Unity of Knowledge, Toronto-London, University of Toronto Press.

CHALMERs David, (2006), "Strong and Weak Emergence," in P. Clayton \& P. Davis (eds.), The ReEmergence of Emergence, Oxford, Oxford University Press, 244-55.

CHAMBLISS Joseph James, (1960), "Natural Selection and Utilitarian Ethics in Chauncey Wright," in American Quarterly, 12, 2 (1), 144-59. 
CHAMBLISS Joseph James, (1964), “Chauncey Wright's Enduring Naturalism," in American Quarterly, 16 (4), 628-35.

CLAYTON Philip \& Paul DAVIS (eds), (2006), The Re-Emergence of Emergence, Oxford, Oxford University Press.

CORRADINI Antonella \& Timothy O'CONNOR (eds), (2010), Emergence in Science and Philosophy, New York, Routledge.

CRANE Tim (2001), "The Significance of Emergence," in C. Gillett \& B. Loewer (eds), Physicalism and Its Discontents, Cambridge, Cambridge University Press, 207-24.

DARWIN Charles R., (1859), On the Origin of Species, London, John Murray; 6th edition, London, Murray, 1872.

DARWIN Charles R., (1868), The Variation of Animals and Plants under Domestication, 2 vols., London, John Murray.

DARWIN Charles R., (1871), The Descent of Man, and Selection in Relation to Sex, 2 vols., London, John Murray.

DE GROOT Jean, (2004), Homegrown Positivism: Charles Darwin and Chauncey Wright, in Id. (ed.), Nature in American Philosophy, Washington, D. C., The Catholic University of American Press, 53-71.

D'ERRICO Francesco \& Ivan COLAGÈ, (2018), “Cultural Exaptation and Cultural Neural Reuse: A Mechanism for the Emergence of Modern Culture and Behavior," Biological Theory, 13 (4), 213-27. DEWEY John, (1910), The Influence of Darwin on Philosophy, and Other Essays in Contemporary Thought, New York, Henry Holt and Co.

DEWEY John, (1925a), Experience and Nature, London, George Allen \& Unwin.

DEWEY John, (1925b), The Development of American Pragmatism, in Studies in the History of Ideas, New York, Columbia University Press, v. II, 351-77.

DE WOLFE HOWE Mark (ed.), (1953), Holmes-Laski Letters: The Correspondence of Mr. Justice Holmes and Harold J. Laski, 2 vols., Cambridge, Harvard University Press.

DOAT David \& Olivier SARTENAER, (2014), “John Dewey, Lloyd Morgan et l'avènement d'un nouveau naturalisme pragmatico-émergentiste," Philosophiques, 41 (1), 127-56.

EL-HANI Charbel Niño \& Sami PIHLSTRÖM, (2002), "Emergent Theories and Pragmatic Realism," Essays in Philosophy, v.3 (2), art. 3 [commons.pacificu.edu/eip/vol3/iss2/3/].

FABBRICHESI Rossella, (2009), "Il pragmatismo: un nome nuovo per un modo di pensare antico," in L. Sanò (ed.), Il destino di Prometeo, Padova, Il Poligrafo.

FABBRICHESI Rossella, (2011), "Effects of Truth: The Darwinian Revolution and Its Impact on Pragmatism," in R. Frega \& R. Brigati (eds), Pragmatist Epistemologies, Lanham (MD), Lexington.

FISCH Max H., (1947), “Evolution in American Philosophy," Philosophical Review, 56, 357-73; now in RYAN (2000), 91-107.

FISCH Max H., (1966), “General Introduction,” in Id. (ed.), Classic American Philosophers, New York, Fordham University Press, 1-40.

FITCH Tecumseh W., (2012), “Evolutionary Developmental Biology and Human Language Evolution," Evolutionary Biology 39, 613-37.

FRANCESCOTTI Robert, (2007), “Emergence,” Erkenntnis, 67 (1), 47-63. 
GINZBURG Carlo, (1983), "Morelli, Freud, and Sherlock Holmes: Clues and Scientific Method," in U. Eco \& T. A. Sebiok (eds), The Sign of Three: Dupin, Holmes, Peirce, Bloomington, Indiana University Press, 81-118.

Gould Stephen J., (1977), Ever since Darwin: Reflections in Natural History, Norton \& Company, New York-London.

GOULD Stephen J., (2002), The Structure of Evolutionary Theory, Cambridge, Mass., Harvard University Press.

GOULD Stephen J. \& Elisabeth S. VRBA, (1982), "Exaptation - a Missing Term in the Science of Form," Paleobiology, 8 (1), 4-15.

HEMPEL Carl G. \& Paul OPPENHEIM, (1948), "Studies in the Logic of Explanation," Philosophy of Science, $15(2), 135-75$.

HUXLEY Thomas, (1881), “On the Method of Zadig: Retrospective Prophecy as a Function of Science," in Science and Culture, London, Macmillan.

JACOB François, (1977), “Evolution and Tinkering,” Science, n.s, v. 196 (4295), 1161-6.

JAMES William, (1978), Pragmatism and The Meaning of Truth, Cambridge, Mass., Harvard University Press.

KAUfFMAnN Stuart A., (2019), A World Beyond Physics. The Emergence and Evolution of Life, New York, Oxford University Press.

KENNEDY Gail, (1935), The Pragmatic Naturalism of Chauncey Wright, in Studies in the History of Ideas, 3; now in RYAN (2000), 171-90.

KIM Jaegwon, (1999), “Making Sense of Emergence," Philosophical Studies 95, 3-36.

KIM Jaegwon, (2006), “Emergence: Core Ideas and Issues,” Synthese, 151 (3), 547-59.

KUPIEC Jean-Jacques \& Pierre SONIGO, (2000), Ni Dieu ni gène. Pour une autre théorie de l'hérédité, Paris, Éditions du Seuil.

LEWES George H., (1875), Problems of Life and Mind, v. 2, London, Kegan Paul, Trench, Turbner and Co.

LLOYD MORGAN Conwy, (1923), Emergent Evolution, London, Williams and Norgate.

MADDEN Edward H., (1952), “Chauncey Wright: Forgotten American Philosopher," American Quarterly 4, 25-34; now in RYAN (2000), 35-45.

MADDEN Edward H., (1954), "Wright, James and Radical Empiricism," The Journal of Philosophy, 51 (26), 868-74.

MADDEN Edward H., (1963), Chauncey Wright and the Foundations of Pragmatism, Seattle, University of Washington Press.

MADDEN Edward H., (1964), Chauncey Wright, New York, Washington Square Press.

MAYR Ernst, (1982), The Growth of Biological Thought. Diversity, Evolution, and Inheritance, Cambridge (Mass.)-London, Harvard University Press.

MCGRANAHAN Lucas, (2017), Darwinism and Pragmatism: William James on Evolution and Self-

Transformation, London-New York, Routledge. 
MCLAUGHLIN Brian, (1992), “The Rise and Fall of British Emergentism," in Beckermann A., Flohr A. \& Kim J. (eds), Emergence or Reduction? Essays on the Prospects of Nonreductive Physicalism, BerlinNew York, De Gruyter, 49-93.

MEAD George H., (1932), The Philosophy of the Present, ed. by A. E. Murphy, Chicago, Open Court Pub.; repr. 2002, New York, Prometheus Books.

MEAD George H., (1934), Mind, Self, and Society: From the Standpoint of a Social Behaviorist, ed. by Charles W. Morris, Chicago, University of Chicago Press.

MEAD George H., (1938), The Philosophy of the Act, ed. by Charles W. Morris, Chicago, University of Chicago Press.

MENAND Louis, (2001), The Metaphysical Club. A Story of Ideas in America, New York, Farrar, Straus \& Giroux.

MILL James, (1829), Analysis of the Phenomena of the Human Mind, 2 vols., London, Baldwin \& Cradock; 2nd edition 1878, London, Longmans, Green, Reader and Dyer.

MILL John Stuart, (1843), A System of Logic, Ratiocinative and Inductive, Being a Connected View of the Principles of Evidence, and the Methods of Scientific Investigation, 2 vols, London, John W. Parker, vol. 1.

MIVART St. George J., (1871), On the Genesis of Species, London, Macmillan and Co.

NAGEL Ernst, (1961), The Structure of Science. Problems in the Logic of Scientific Explanation, New York, Harcourt, Brace and World.

NORTON Charles E., (1877), Biographical Sketch of Chauncey Wright, in Wright (1877), vii-xxiii.

O'CoNNOR Timothy, (1994), “Emergent Properties," American Philosophical Quarterly, 31 (2), 91-104.

OKASHA Samir, (2012), "Emergence, Hierarchy and Top-Down Causation in Evolutionary Biology," Interface Focus, 2 (1), 49-54.

PARRAVICINI Andrea, (2009), “A New Use for an Old Theory: Chauncey Wright between Darwinism and Pragmatism," Cognitio-Estudos, 6 (2), 110-8 [revistas.pucsp.br/cognitio/article/view/5825]. PARRAVICINI Andrea, (2011), Un incontro tra darwinismo e pragmatismo: la filosofia evoluzionistica di Chauncey Wright, Doctoral thesis, State University of Milan [air.unimi.it/handle/2434/151788]. PARRAVICINI Andrea, (2012), Il pensiero in evoluzione. Chauncey Wright tra darwinismo e pragmatismo, Pisa, ETS.

PARRAVICINI Andrea \& Telmo PIEVANI, (2018), "Continuity and Discontinuity in Human Language Evolution: Putting an Old-Fashioned Debate in its Historical Perspective," Topoi, 37 (2), 279-87.

PEARCE Trevor, (2015), “'Science Organized': Positivism and the Metaphysical Club, 1865-1875,” Journal of the History of Ideas, 76 (3), 441-65.

PEARCE Trevor, (2020), Pragmatism's Evolution: Organism and Environment in American Philosophy, Chicago-London, University of Chicago Press (forthcoming).

PEIRCE Charles S., (1931-1958), Collected Papers of Charles Sanders Peirce (C. Hartshorne \& P. Weiss (eds), vols. 1-6, 1931-5; A. W. Burks (ed.), vols. 7-8, 1958), Cambridge, Mass., Harvard University Press.

PIEVAni Telmo, (2015), Philosophy of Selection (Natural, Sexual and Drift), in eLS, John Wiley \& Sons, Ltd, Chichester:1-5 [doi.org/10.1002/9780470015902.a0003461]. 
PIHLSTRÖM Sami, (2002), “The Re-Emergence of the Emergence Debate," Principia, 6 (1), 133-82. RATNER Sidney, (1936), "Evolution and the Rise of Scientific Spirit in America," Philosophy of Science, 3, 104-22; now in RYAN (2000), 49-63.

RYAN Frank X. (ed.), (2000), Influence and Legacy, in The Evolutionary Philosophy of Chauncey Wright, 3 vols., Bristol-Sterling, Thoemmes Press, vol. 3.

SAWYER Keith R., (2002), "Emergence in Psychology: Lessons from the History of Non-Reductionist Science," Human Development 45, 2-28.

SCHILLER Ferdinand Canning Scott, (1930), “Creation, Emergence, Novelty," Proceedings of the Aristotelian Society, New Series, 31, 25-36.

SCHNEIDER Herbert W., (1946), A History of American Philosophy, New York, Columbia University Press.

SEIDEL Marc-David L. \& Henrich R. GREVE, (2017), Emergence: How Novelty, Growth, and Formation Shape Organizations and Their Ecosystems, Bingley (UK), Emerald Group Publishing.

SINI Carlo, (1972), Il pragmatismo americano, Bari, Editori Laterza.

STEPHAN Achim, (1992), "Emergence - A Systematic View of Its Historical Facets," in Beckermann A., Flohr A. \& Kim J. (eds), Emergence or Reduction? Essays on the Prospects of Nonreductive Physicalism, Berlin-New York, De Gruyter, 25-48.

TATTERSALL Ian, (2014), “An Evolutionary Context for the Emergence of Language,” Language Sciences 46, 199-206.

VAN GULICK Robert, (2001), "Reduction, Emergence and Other Recent Option on the Mind/Body Problem: A Philosophic Overview," Journal of Consciousness Studies, 8 (9-10), 1-34.

WALLACE Alfred R., (1869), "Sir Charles Lyell on Geological Climates and the Origin of Species," in Quarterly Review, 126 (252), 359-94.

WALLACE Alfred R., (1870), “The Limits of Natural Selection as Applied to Man," in Id., Contributions to the Theory of Natural Selection, London, Macmillan, 332-71.

WHITE Morton, (1972), "Chauncey Wright: Empiricist Philosopher of Evolutionary Science," in Id., Science \& Sentiment in America, London-Oxford-New York, Oxford University Press, 120-43.

WIENER Philip P., (1945), "Chauncey Wright's Defense of Darwin and the Neutrality of Science," Journal of the History of Ideas 6; now in RYAN (2000), 64-90.

WIENER Philip P., (1949), Evolution and The Founders of Pragmatism, Cambridge, Mass., Harvard University Press; 2nd edition 1965, New York, Harper and Row.

WRIGHT Chauncey, (1865a), “The Philosophy of Herbert Spencer," North American Review, 100 (207), April, 423-76; now in PD, 43-96.

WRIGHT Chauncey, (1865b), “E. L. Youmans's Correlation and Conservation of Forces," North American Review, 100 (207), 619-23.

WRIGHT Chauncey, (1866), “Spencer's Biology," The Nation, 2 (55), June 8, 724-5.

WRIGHT Chauncey, (1870), "Limits of Natural Selection," North American Review, Oct.; now in PD, 97-127. 
WRIGHT Chauncey, (1871a), "The Genesis of Species," North American Review, Jul.; now in PD, 126-67. Repr. in UK, with some additions, Darwinism: Being an Examination of Mr. St. George Mivart's "Genesis of species," London, John Murray, 1871.

WRIGHT Chauncey, (1871b), “The Uses and Origin of the Arrangements of Leaves in Plants,"

Memoirs of the Academy of Arts and Science (NS), v.9 (2), Oct.10, 379-417; now in PD, 296-328

(abridged version).

WRIGHT Chauncey, (1872), "Evolution by Natural Selection," North American Review, Jul.; now in PD, 168-98.

WRIGHT Chauncey, (1873), “The Evolution of Self-Consciousness," North American Review, Apr.; now in PD, 199-266.

WRIGHT Chauncey, (1877), Philosophical Discussions, ed. by C. E. Norton, New York, Burt Franklin; now repr. in Wright C. (2000), The Evolutionary Philosophy of Chauncey Wright, ed. by F. X. Ryan, 3 vols., Bristol-Sterling, Thoemmes Press, vol.1 [PD].

WRIGHT Chauncey, (1878), The letters of Chauncey Wright, ed. by J. M. Thayer, Cambridge, Mass., J. Wilson \& Son; now repr. in Wright C. (2000), The Evolutionary Philosophy of Chauncey Wright, ed. by F. X. Ryan, 3 vols., Bristol-Sterling, Thoemmes Press, vol. 2 [LCW].

ZНок Andrea, (2011), Emergentismo. Le proprietà emergenti della materia e lo spazio ontologico della coscienza nella riflessione contemporanea, Pisa, Edizioni ETS.

\section{NOTES}

1. See Beckerman, Flohr \& Kim 1992; Bedau \& Humphreys 2008; Clayton \& Davis 2006; Corradini \& O'Connor 2010; Francescotti 2007; Kauffman 2019; Kim 1999, 2006; Okasha 2012; Pihlström 2002; Seidel \& Greve 2017; Van Gulick 2001.

2. See Stephan 1992 for a historical and conceptual reconstruction of the different outlines characterizing the emergentist tradition.

3. To quote a couple of examples, in Experience and Nature Dewey defines his philosophical reflections about mind as "an attempt to contribute to what has come to be called an 'emergent' theory of mind" (Dewey 1925a: 271), while Schiller examines the notions of "emergence" and "novelty" in his article entitled Creation, Emergence, Novelty (1930). See El-Hani \& Pihlström 2002; Sawyer 2002; Doat \& Sartenaer 2014; Baggio 2015, and the articles in this EJPAP special issue, some of which also compare James and Peirce's pragmatism with the emergentist tradition.

4. For further bibliographic details, see Brioschi (2019: 2.1).

5. Laski recalls this episode in a letter dated 3 September 1931 and addressed to Oliver Wendell Holmes Jr. (1841-1935), a judge of the US Supreme Court and a crucial figure of the Metaphysical Club in Cambridge (Mass.), where pragmatism was born as a philosophical movement (Menand 2001).

6. For a full list of Wright's works and critical studies on his thought, see Parravicini 2011. On Wright's life and career, see Madden 1963, 1964; Menand 2001; Norton 1877; Ryan 2000; Sini 1972; Wiener 1949; Wright 1878.

7. On the close relationship between Darwinism and classical pragmatism, see Fabbrichesi 2011; Mc Granahan 2017; Menand 2001; Parravicini 2009, 2012; Pearce 2020; Sini 1972; Wiener 1949.

8. "Positivism, to be sure, so far as it pretends to be a philosophy at all is more than the body of the sciences. It must be a system of the universal methods, hypotheses and principles which are founded on them, and if not a universal science in an absolute sense, yet must be coextensive with actual knowledge and exhibit the consilience of the sciences" (Wright to Abbot, February 10, 
1869, in LCW: 141). See Pearce 2015, and De Groot 2004 on Wright's non-canonical (and not specifically Comtean) positivism.

9. This is how O. W. Holmes Jr. referred to Wright in a letter (see Wiener 1949: 174). Madden (1952) wrote an essay entitled Chauncey Wright: Forgotten American Philosopher. Nevertheless, at the beginning of the new millennium interest in Wright was renewed by the reprint of his Philosophical Discussions (1877, PD), along with his Letters (1878, LCW) and a series of old essays by various scholars on different aspects of Wright's thought (Ryan 2000).

10. See Fabbrichesi 2009. See also below, section 5 .

11. Darwin explained this point in 1868, II:248-9; 431.

12. Wiener 1945, 1949. See also PD: 136-8.

13. The Latin term evolutio designates the act of unfolding something, e.g. a roll of parchment. This term was used by those pre-Darwinian biologists of the 18th century who supported a "preformational" view, according to which the evolutionary process was assimilated to the unfolding of the immanent potential of an Essence, preformed and not changeable from the beginnings. See Gould (1977: 34-5).

14. The peculiar logical structure of this kind of postdictive inference that we may call - in the words of Huxley (1881) - a "retrospective prophecy" (see also Ginzburg 1983) recalls what Peirce named "retroduction." We leave the attempt to prove this connection up to future studies, as this would lead us too far from our current goal. However, if this link were confirmed, the logic of retroduction that supports pragmatist philosophy as a guiding principle could somehow be acknowledged as the kind of inference that drives the "retrospective prophecies" of the Darwinian scientists.

15. François Jacob 1977 drew an analogy between the evolutionary process and the activity of the bricoleur.

16. See also Gould (2002: ch. XI). For an in-depth comparison between the modern notion of exaptation and Wright's principle of uses, see Parravicini (2012: 169-94).

17. See Gould (2002: ch. XI) on Darwin's arguments against Mivart's objections and Parravicini (2012: ch.3) on Wright's arguments against Mivart.

18. See, e.g., D'Errico \& Colagè 2018; Fitch 2012; Parravicini \& Pievani 2018; Tattersall 2014.

19. As Kupiec \& Sonigo $(2000: 14-5)$ argue, according to an instructive model "[l]e résultat du processus préexiste toujours, de manière virtuelle, au processus réel. Le moule définit le résultat avant qu'il n'apparaisse. Dans la version darwinienne c'est rigoureusement l'inverse: la pâte à modeler se transforme spontanément et [...] le résultat ne préexiste pas."

20. Many studies have revealed the great influence that Wright's conceptions exerted on James. See Kennedy (1935); Madden (1954; 1963: 128-42; 1964: 108, 130-1); Schneider (1946: 539); Wiener (1949: 54-5). R. B. Perry wrote that "It is impossible to read the Evolution of self-consciousness without being constantly reminded of James" (Ryan 2000: 145). On James' views, see the very recent Bella 2019.

21. The same example about "force" is found in Peirce's How to make our ideas clear (1878: CP 5.403).

22. See, e.g., Mead ([1932] 2002: 45-6) and Mead (1938: 413). On Mead's emergentism see also Baggio 2019. 


\section{ABSTRACTS}

The notion of "emergence" has recently received renewed attention in research fields ranging from biology to cognitive sciences and philosophy of mind. Today's concept of "emergence" incorporates a long history of philosophical debates and reflections that can be traced back to James and John Stuart Mill and nineteenth-century associationist philosophy. This tradition reached its theoretical maturity in the early twentieth century with so-called classical British emergentism, which gained the attention of pragmatist philosophers from the beginning. In the current literature exploring the relationship between Pragmatism and the emergentist tradition, almost nothing is said about the interesting case of Chauncey Wright (1830-1875), a follower of J. S. Mill and A. Bain, and a crucial figure for the origins of pragmatist philosophy. After a brief historical introduction about the history of the notion of "emergence" and its relationship to classical Pragmatism, the paper aims to examine Wright's philosophy in relation, on one hand, to the pragmatist tradition and, on the other hand, to the problem of emergence. In the wake of Wright's original interpretation of Darwin's evolutionary theory, the article focuses on the key notions of "novelty" and "new uses," through which Wright developed an "emergentist" philosophy that was well ahead of its time and attracted the interest of Samuel Alexander, one of the major philosophers of classical British emergentism. In the second part, the paper analyzes Wright's reflections about the origin of human self-consciousness as a paradigmatic case of authentic evolutionary novelty. In the final part, the article focuses on the kind of pragmatic realism sketched out by Wright and summarizes the most important aspects to have emerged during the scholarly debate on the topic.

\section{AUTHOR}

\section{ANDREA PARRAVICINI}

Università degli Studi di Milano

andrea.parravicini[at]unimi.it 